\title{
Industrialisation
}

and Culture

|830-19|4 


\section{Industrialisation and Culture 1830-1914}

edited by

Christopher Harvie, Lecturer in History

Graham Martin, Reader in Literature

Aaron Scharf, Professor in Art History

at the Open University

published by

Macmillan for

The Open University Press 
(C) The Open University 1970

All rights reserved. No part of this publication may be reproduced or transmitted, in any form or by any means, without permission.

\author{
First published 1970 by \\ MACMILLAN AND CO LTD \\ London and Basingstoke \\ Associated companies in New York Toronto \\ Dublin Melbourne Johannesburg and Madras \\ ISBN 978-1-349-86189-7 (eBook) \\ DOI 10.1007/978-1-349-86189-7
}

ISBN 978-0-333-11702-6

The Papermac edition of this book is sold subject to the condition that it shall not, by way of trade or otherwise, be lent, resold, hired out, or oth erwise circulated without the publish er's prior consent, in any form of binding or cover other than that in which it is published and without a similar condition including this condition being imposed on the subsequent purchaser. 


\section{Contents}

Introduction

Acknowledgements

\section{Part One}

A The Mechanical Age

1 Thomas Carlyle: The Mechanical Age 21

2 William Bell Scott: The Industry of Newcastle 26

B The Face of the Country

1 George Eliot: A Midland Journey 29

2 Gustave Doré: Under the Viaduct 37

3 Alexis de Tocqueville: Manchester 39

C Machinery

1 Erasmus Darwin: The Steam Engine 45

2 Joseph Wright of Derby: An Experiment on a Bird in an Air-pump

3 I. K. Brunel: The New Machine 48

4 A Textile Mill in the 1830s 51

5 Henry Morley: Ground in the Mill 52

6 'Captain Swing': A Threat to Wreck a Threshing Machine

7 A Steam Thresher at Work

8 Steamer and Locomotive: The Elegance of the

D Enterprise

1 The Industries of the Monklands

2 Sir William Fairbairn

3 Sir Arthur Helps: Thomas Brassey at Work 
E Communications

1 The Liverpool and Manchester Railway

2 The Coming Railway Age: 'The Scotsman'

3 Charles Rossiter: 'To Brighton and Back for Three and Sixpence'

4 The Investments of Professor and Mrs T. H. Green $\quad 86$

5 Cuthbert Brodrick: The Grand Hotel, Scarborough 88

6 The Journeys of James Bryce

F Transition

1 William Cobbett: A Farm Sale near Reigate 95

2 'The Oldham Weaver' 100

3 Hugh Miller: The Masons on Strike and at Play 104

4 Women in the Mines, $1842 \quad 108$

5 Alexander MacDonald: Working Conditions in Scottish Mines

6 Alexander MacDonald: Biographical Sketch

7 James Phillips Kay: The Manchester Cotton Workers 113

8 Eyre Crowe: The Factory Girls' Dinner Hour, Wigan 118

9 Henry Mayhew: The London Scavenger

10 Charles Dickens: A Walk in a Workhouse

G Responses

$1 \quad$ Friedrich Engels: Trade Unionism

2 United and Industrious: à Trade Union Certificate, 1851

3 Edwin Chadwick: Conclusions from the Sanitary Report, 1842

4 W. E. Forster: Introduction of the Education Bill, 1870

5 Beatrice Webb: Co-operation and Nonconformity in Bacup 
Part Two

H Prophets and Sceptics

1 Adam Smith: The Division of Labour 158

2 Karl Marx: The Manchester Party 161

3 Marriott's Free Trade Hat, 1844

4 Goldwin Smith: The Laws of Political Economy 165

5 James Bryce: The Approaching Democracy

167

6 John Stuart Mill: The Peril of Uniformity

7 Matthew Arnold: Culture and Machinery

8 Thomas Carlyle: The Irish

9 Thomas Carlyle: Hudson's Statue

10 A. W. N. Pugin: Contrasted Towns

11 John Ruskin: True and False Economy 188

12 William Morris: How I Became a Socialist 191

13 Art in the Service of Socialism

$\mathrm{J} \quad$ Religion and Materialist Philosophy

1 Thomas Henry Huxley: The Automatism of Animals

2 William Kingdon Clifford: Body and Mind

3 Henry Longueville Mansel: Limits of Religious Thought

4 Leslie Stephen: Religion as a Fine Art

$$
\text { Part Three }
$$

K The Great Exhibition

1 George Cruikshank: The Queen Opening the Great Exhibition

2 Prince Albert's Opening Speech and Her Majesty's Reply

3 W. M. Thackeray: Mr Molony's Account of the Crystal Palace

4 George Cruikshank: London in 1851

5 Henry Mayhew: 1851; or the Adventures of $\mathrm{Mr}$ and Mrs Sandboys 


\section{Contents}

K The Great Exhibition (contd.)

6 Thomas B. Onwhyn: Mr and Mrs John Brown's Visit to London to See the Grand Exposition of all Nations 250

L Art and Design

$1 \quad$ I. K. Brunel to Digby Wyatt: The Building of Paddington Station

2 William Powell Frith: Paddington Station

3 W. Cooke Taylor: Art and Manufacture

4 European Revolution and British Art

5 Robert Hunt: Science and the Arts

6 Opper: Signs of the Times - Household Patents in the 1890s

7 A Couple of Mistakes in Candlesticks

8 Standards of Design, 1846

9 Which Direction for Ornamental Art?

10 Roger Fry: Art and Socialism

11 Lewis Foreman Day: The Ornament of the Future

12 Calotype Photograph by David Octavius Hill and Robert Adamson

13 Elizabeth, Lady Eastlake. Photography

14 Talbot's Calotype Printing Establishment at Reading

15 Pictures for the Millions

16 Monster American Camera Demonstrated at the 1900 Paris Exhibition

17 W. K. L. Dickson Filming the Boer War

5 The Work of Iron 
N William Morris

1 Ford Madox Brown: 'Work' 318

2 A Dream of Ease $\quad 321$

3 On the Lack of Incentive to Labour in a Communist Society

4 The Prospects of Architecture in Civilisation 324

5 The Vulgarisation of Oxford

6 The Old Alhambra in the 1890s

7 Art under Plutocracy

8 The Revival of Handicraft 334

9 The Lesser Arts of Life 336

10 Photo-journalism: John Thomson, 'The Crawlers' 338

11 Art and Socialism

O Looking Forward

1 Advertising by Photomontage

2 The Utilitarian Ornaments Art

3 Telephone Exchange, Lime Street, London, 1900

351

4 Defects in Wire Photos

5 Traffic in Fleet Street, 1905

6 Henri Fournier: The Coming of the Automobile

7 Traffic in Fleet Street, 1924

8 Blériot's Cross-Channel Flight, 1909

355

9 The Military Automobile - Revolver Style

\section{Part Four}

P Literature

1 Alfred, Lord Tennyson: Liberal Doubts

2 Mrs Elizabeth Gaskell: Chartists

3 Thomas Hood: Liberal Sympathy

375

4 Charles Dickens: The Industrial Environment

5 Charles Dickens: A Marriage Contract

6 Thomas Hardy: Agricultural Machinery

7 Matthew Arnold: The Crisis in Belief 


\section{Contents}

P Literature (contd.)

8 Mark Rutherford: Clerical Work 399

9 Tom Maguire: Socialist Polemic 402

10 Joseph Conrad: Bringing Civilisation to Africa 404

11 H. G. Wells: The Role of Advertising 411

12 G. B. Shaw: Power and Morality 417

13 E. M. Forster: Money and the Pursuit of Culture 425

14 H. G. Wells: Technology and the Future 430

15 D. H. Lawrence: The Social Machine 438

Notes on the Editors $\quad 447$

Index $\quad 449$ 


\section{Introduction}

This book was conceived as a collection of readings to be used in association with the correspondence material and radio and television broadcasts of the last eight units of the foundation course in the Humanities at the Open University. The rationale of this 'extended case study' is best given in the brief introduction which Graham Martin, chairman of the working group, drafted:

The purpose of this block of units is to explore selected aspects of the complex and deep-seated changes in British society that resulted from the process known as 'industrialisation'. This process may seem, at first sight, a simple affair, having principally to do with the appearance of the familiar industrial 'landscape', with its factories, mills, coalmines, and associated ports and railways. But there was much more to it than that. Generally, we can say that industrialisation disrupted traditional patterns of social life. It made available a new richness of individual experience in some directions but in others it imposed new constraints, some of them more tyrannical than any that had existed in the past.

Physically, it liberated man by overcoming the barrier of distance, by cheapening commodities, and by diversifying social experiences. Politically, it helped to release him from the encumbrance of prescriptive privilege and traditional inequality. Philosophically, it was accompanied by a change in man's ways of thinking of himself, a change from the idea of man as a child of God to man as a child of nature, no less an object for scientific investigation than other natural phenomena.

But it also produced widespread misery from the living conditions and economic exploitation suffered, especially by its first victims, the labouring poor, or, as they came to be known, the working class. And there were more subtle effects. Contemporary thinkers maintained that it promoted a commercial spirit which damaged the quality of personal and social relationships, encouraged a competitive self-interest, depreci- 


\section{Introduction}

ated the life of the feelings and the values of art, and seriously disturbed the balance between man and the world of nature. Yet, paradoxically, by stimulating this debate, it also created a keener awareness and a fuller understanding of the values that it threatened.

It is because industrialisation affected human life in these deeper, less obvious ways that we have entitled the block 'Industrialisation and Culture'. In this context, the term 'culture' means 'the intellectual and artistic activities of a society', and the full nature of historical change can only be understood by giving them adequate attention.

The first two units examine the 'industrialising' of an activity transport in this case - and its implications in social and personal terms. The third unit discusses the debate between the proponents and critics of industrial change. The fourth unit is devoted to some philosophical consequences of the application of the methods of the natural sciences to the study of man and his mind. The fifth and sixth deal with industry and art: the implications for the artist of new techniques and materials, the relationship of the arts and public taste, and the role of the artist as a critic of society. The last two units concentrate on D. H. Lawrence's novel 'The Rainbow', in its reflection of some social changes brought about by industrialisation, and of Lawrence's critical view of these changes.

In its layout 'Industrialisation and Culture' corresponds roughly to the progression, history-social criticism and philosophy-artliterature. The editors divided their labour appropriately: Christopher Harvie dealt with the first two sections, Aaron Scharf with the third, and Graham Martin with the fourth, although there was a great deal of cross-discipline collaboration in each.

Three factors have, broadly speaking, governed the choice of extracts: possible use within the structure of the correspondence units, as material for exercises and assignments; value as illustrations of aspects of the age; and, especially in the first section, the desire to indicate something of the variety of types of source material available to the historian.

Techniques of presenting the extracts have varied. Where the range of subjects covered is considerable, as in the first section, separate and extended introductions have been written to each extract. Where the 
documents relate more closely to one another in subject-matter, the introductions to specific extracts have been abbreviated and lengthier introductions to groups of extracts substituted. Extracts are given a letter and number identification which relates to their position in each section - e.g. D2 refers to the 'Dictionary of National Biography' article on Sir William Fairbairn, the second extract in the 'Enterprise' section - which should provide a simple system of reference. Suggestions for further reading have been given where appropriate.

Finally the editors would like to thank all the members of the foundation course team of the Arts Faculty for their help and encouragement in this project. Particular thanks must go to Godfrey Vesey, who selected the extracts for the philosophy section, to Arthur Marwick for much helpful advice about the arrangement of the first section, and to the Dean, John Ferguson, for his enthusiasm and understanding. Not to speak, of course, of our secretaries, who turned chaos into order.

Christopher Harvie Graham Martin Aaron Scharf 


\section{Acknowledgements}

Grateful acknowledgement is made to the following sources for material used in this book:

Edward Arnold (Publishers) Ltd for extract from E.M. Forster's 'Howards End'; Balliol ollege, Oxford, for extract from T. H. Green's 'Green Papers'; Mrs Dorothy Cheston Bennett and Methuen \& Co. Ltd for extract from 'Clayhanger' by Arnold Bennett; the Bodleian Library, Oxford, for 'Bryce Papers E. 30', Robinson Ellis to James Bryce, 1 July 1860; 'Modern English Biography', reprinted by permission of the publishers, Frank Cass \& Co. Ltd, London, 1965; Chatto \& Windus Ltd for extract from 'Vision and Design' by Roger Fry, and for extract from 'Art' by Clive Bell; J. M. Dent \& Sons Ltd for extract from 'The Heart of Darkness' by Joseph Conrad; the London School of Economics and Political Science for extract from 'My Apprenticeship' by Beatrice Webb; J.P. Mayer for translation from Alexis de Tocqueville, 'Notes on England' (Faber, 1957); Laurence Pollinger Ltd for extract from D. H. Lawrence, 'Twilight in Italy'; the Society of Authors for extract from 'Major Barbara', Act 3, by George Bernard Shaw; the estate of H.G. Wells for extracts from 'The War of the Worlds' and 'Tono Bungay' by H. G. Wells. The publishers have been unable to trace the copyright-holders of some extracts, but will be pleased to make the necessary arrangement at the first opportunity. 